\title{
MARKET ENVIRONMENT FACTORS INFLUENCEON DEVELOPMENT OF BANCASSURANCE IN LATVIA
}

\author{
EviJa Dundure ${ }^{1}$, Biruta Sloka ${ }^{2}$ \\ Latvia University (Latvia)
}

\begin{abstract}
Banks and insurers as part of financial service industry engage in partnership under the concept of Bancassurance. Several studies are done on this topic, focusing on economies of scale and performance of most Bancassurance common models. The purpose of this study is to identify the key market environment factors that influence the development of Bancassurance for retail banks in Latvia and the level of increase. Aim of this research is to analyse - how market environment factors influence the development of Bancassurance in Latvia. The current paper is focused on the Latvian market where several Bancassurance models are present as we test our propositions by interviewing management representatives of major stakeholders and analysing secondary market data. Main research findings - motives of banks and insurance companies in Latvia for implementing Bancassurance are in correspondence with the academia: new clients and additional revenue for insurers, improvements of customer service and loyalty for banks. Study results highlight the great impact of economic growth and technological development on Bancassurance over other market-based factors and reflect the importance of their integration for achieving better results in each model.
\end{abstract}

KEYWORDS: bancassurance, banks, insurance, market environment.

JEL CODES: M10; M38

\section{Introduction}

The first apparent evidence of Bancassurance has been recognized by the Johnston (Johnston, 1922: 26) in the beginning of $20^{\text {th }}$ century when legislature of the state of Massachusetts allowed banks to combine both savings and life insurance. By further expansion in Europe and Asia Bancassurance has become the way of synergy where two financial services industries - banks and insurance companies are answering to ongoing challenges in order to expand the operations, reach new clients and make a profitable business.

Bancassurance phenomena has been widely researched by various academics - they are questioning necessity of Bancassurance, analysing different forms of it and summarising consequences it brings to all stakeholders: banks, insurance companies and customers. Most of the research could be categorized in three broad categories: 1) research focusing on accomplishments, profitability, efficiency and diversification; 2) hypothetical studies focusing on consequences of development, impact of regulatory and corporate environment, preferences of financial convergence of financial institution collaboration; 3) there are certain part

1 Evija Dundure - master of social sciences, Arca Infrastruktura Ltd

Scientific field: enterpreneurship and financial services

E-mail: dundure.evija@gmail.com

Tel. +371 29493458

2 Biruta Sloka - prof.habil.dr.oec., University of Latvia, Department of Management Science

Scientific field: management, marketing

E-mail: Biruta.Sloka@lu.lv

Tel. +37129244966 
of studies focusing on how M\&A deal notifications, announcements of regulatory changes and alterations in banking and insurance management affect stock price fluctuation.

Bancassurance in Latvia has been catching up the world-wide trends in the field starting from the beginning of 1990's just after foundation of free capital market. The situation in Latvia during last 30 years has changed dramatically and it is contributively to pay special attention to its impact on the Bancassurance evolution.

This research purpose is to analyse - how market environment factors influence the development of Bancassurance in Latvia.

Tasks: 1) analyze scientific findings in scientific publications and previous conducted research; 2) investigate factors influencing bancassurance development in Latvia; 3) compare differences of representatives of financial market experts and representatives of banks on factors influencing the bancassurance in Latvia.

The academic research results give ground for proposition: Economic growth level and demography issues are negatively influencing development of bancassurance in Latvia while regulation framework, globalization and technological advancement give positive impact.

To test the proposition research methods used: analysis of scientific publications, analysis of previous conducted research, expert survey, case studies analysis. To test the proposition two types of units have been analyzed: total system units -4 representatives from financial institutions, regulatory agencies, financial market experts; and intermediate units -4 management representatives of three largest banks in Latvia. The primary data collection type was semi-structured interviews to collect qualitative information on Bancassurance development factors.

\section{Theoretical findings}

\subsection{Development of Concept of Bancassurance}

From subsidiaries to holding companies and alliances the concept of Bancassurance was constantly transforming to represent the various forms of cooperation of insurance and banking institutions. It was recognized as successful model and in mid-1980 was implemented in countries like France, Spain, Italy, Belgium and Portugal. For example, in Spain, France and Italy it accounted for $2 / 3$ of life insurance premium income whereas in Portugal and Belgium markets it reached 50\%. As for more conservative markets, such as U.K., Germany and Netherlands, Bancassurance exposure was around 10\%. Overall success of this relatively new concept is linked with the fact that life insurance products as opportunities in general insurance business were limited because of technological development of this era. Hence, since the mid-1990 the Bancassurance developed rapidly in other countries around the world as global presence of retail banks and insurance companies made it easy to penetrate American and Asian markets.

According to research findings of Douglas W. Diamond (Diamond, 1984: 403) Bancassurance is favourable from banks and insurers perspective, because it allows to cover short and long-term assets / liabilities, and it opens opportunities for better customer retention.

According to Swiss Re (1992: 4), "Bancassurance can be described as strategy adopted by banks or insurance companies aiming to operate in the financial services market in a more or less integrated manner". In reality, it is systematic exploration of new strategies towards reaching new potential business and private customers.

Therefore, a specific policy of cooperation between two counterparties with goal of distribution of insurance and banking products or services to same customer base are assumed (Norman, 2007: 118). Alavudeen 
and Rosa (Alavudeen, Rosa, 2015: 12) in their research emphasized the synergy - approach of banks and insurers cooperation process.

\subsection{Gains from Bancassurance}

Benoist in his paper (Benoist, 2002: 297) has pointed out that from banks perspective Bancassurance has positive impact on profit margins and client loyalty. Insurance companies use Bancassurance on their competition path for new alternative sales channels in existing markets and new partnership to enter barrier-free markets (Chang, Peng, Fan, 2011: 77; Brophy, 2013: 329). Both counterparts expect increase in revenues from the cooperation, therefore they are looking for the most effective cooperation modes to apply.

In the World Bank research paper (Gonulal, Goulder Lester, 2012: 8) have highlighted the Bancassurance contribution in the intensifying of insurance sphere development thanks to customer relationship with the clients.

Bancassurance as one of non-banking products for the banks helps to increase their segment of mainbank clients. According to Karin Boonlertvanich (Boonlertvanich, 2019: 293) main-bank clients are less sensitive to changing service quality therefore more loyal in long term relationship.Meanwhile for the insurance companies entering into partnership with the bank haveing better repution is the way how to increase the customer satisfaction level due to the fact that customers are tent to be more loyal to the bank as intermediary versus the insurer it represents (Dominique-Ferreira, 2018: 1184).

One could say that bank can exploit infrastructure, personnel and marketing systems to provide the current customers additional non-banking products, especially insurance, without additional investment. Thus, not only enlarging revenues - commission based or profit from insurance operations, but also reducing costs attributable to the banking products. Expansion of scope of the products leads to diversification and innovation culture. It helps to utilize at larger extent current assets of the bank for additional products, balances demand inconsistencies and covers large scope of customer financial services simultaneously - during the same sales process (Bergendahl, 1995: 22).

However, researchers question the impact of banks diversification in insurance products on financial results and performance of the company. They find correlation between size of the bank's assets and financial results as well as diversification negative impact on technical efficiency (Chang, Elyasiani, 2015: 3363; Elyasiani, Wang, 2012: 1421).

The researchers are mphasize the pros and cons of Bancassurance for the customers. Mäenpää and Voutilainen (Mäenpää, Voutilainen, 2011: 543) mphasized Bancassurance customer-centric approach by exploiting the possibility to cross-sell bundled products during "one-stop shopping" especially for SME clients. Artikis, Mutenga and Staikouras (Artikis, Mutenga, Staikouras, 2008: 115) analysed the banking products being bundled with the respective insurance products, such as life insurances with financing products or house insurances with mortgages. The research provided on South Africa by Okeahalam proved Bancassurance product prices advantage over the stand-alone products (Okeahalam, 2008: 147).

Topics on Bancassurance is taking more and more attention by academic researchers in many countries including factors influencing Bancassurance development.

\subsection{Market based Bancassurance development factors}

During the last decades the academic researchers have been investigated the Bancassurance development driving factors and found out some tendencies. Some of the most important factors can be named such as supportive regulatory regime, globalization, economic growth, demography, technologic changes, growing 
customers' expectations as well as companies' internal strategic and operational frameworks (Ryan, 2001: 45, Staikouras, 2006: 141; Artikis, Mutenga, Staikouras, 2008: 113; Falautano, Marsiglia, 2003: 483; Lymberopoulos, Chaniotakis, Soureli, 2004: 44; Soureli, Lewis, Karantinou, 2008: 13). The academic researcher Staikouras (2006) was the one who made a categorisation of the factors into 2 parts: market-based (exogenous) and operational-based (idiosyncratic) factors.

External factors create the basis of environment for the businesses in definite market. Economic growth, demographics, regulation and the tax environment have been titled as main market-based factors by Staikouras.

Economic indicators, including economic growth, illustrates the development of market, its ability to produce and buy as well as necessity to be financed and insured. Financial service markets are much more sophisticated in developed countries in comparison with developing ones. Even within one region the diverse market situation in countries dictates different Bancassurance development trends. Researchers from Asia in their papers (Fan, Cheng, 2011: 1889) demonstrated how Bancassurance models vary across Taiwan and China and give unequal suggestions for their development.

While economic growth and demographic parameters are interconnected and not so rapidly changeable, regulation framework fully depends on local government's policy and thus affects business environment very directly. Benoist in his paper (Benis,t 2002: 297) has pointed out that one of the core driving forces for Bancassurance's worldwide development in 1990's and 2000's was divergence of regulatory and legislative environment. This allowed banks and insurance companies to enter new markets and establish activities in such regions like Asia, Northern Europe and South America. Furthermore, Jongeneel in his research results publication (Jongeneel, 2011: 36) has argued on the significance of deregulations positive effect on Bancassurance development in 17 European countries from 2000 to 2010. Z. Chen, D. Li, L. Liao, F. Moshirian and C. Szablocs (Chen et al., 2009: 637) have argued that primary determinant of Bancassurance's success in 21 st century for companies operating in more than 25 developed countries has been the great level of deregulation.

Artikis, Mutenga and Staikouras in their paper (Artikis, Mutenga, Staikouras, 2008: 112) in line with just mentioned ones have emphasised the globalization impact on consolidation decisions for banks and insurers. By globalization it is assumed liberalization of national markets for the foreign companies not only to enter by partnership without physical presence in it, but also start full operations without barriers.

Ryan in his research (Ryan, 2001: 44) highlighted the "cross-segment" convergence of banking and insurance as the natural way to maximize profits and increase competitiveness driven by global market changes. Among the main factors forcing the convergence Ryan named globalization, new technology, deregulation and market liberalization, demographics, increasingly sophisticated consumers (Ryan, 2001: 45). The academic researcher emphasised the growing role of global regulation system of financial conglomerates implementing the geographic diversification or e-commerce sales strategies.

I. Falautano and E. Marsiglia (Falautano, Marsiglia, 2003: 483) chose three Bancassurance main evolution drivers to analyze: regulations, technologies, consumption and need to be satisfied. Technological development is giving ground to costs efficiency in sales network establishment and service delivery. They stressed in their research that Bancassurance as first generation of distribution channels and online sales and call centres as the second generation of distribution channels and as such Bancassurance had come to the next phase of development and level of challenges after the rapid growth and expansion across the Europe.

In the Table 1 the market-based factors driving the development of Bancassurance according to references are structured. 
Table 1. Market based Bancassurance factors

\begin{tabular}{ll}
\hline Factors & References \\
\hline Economic growth & Staikouras (2006) \\
Demographics & Artikis, Mutenga, Staikouras (2008) \\
& Ryan (2001) \\
& Staikouras (2006) \\
Regulation & Artikis, Mutenga, Staikouras (2008) \\
& Ryan (2001) \\
& Falautano, Marsiglia (2003) \\
The tax environment & Staikouras (2006) \\
& Artikis, Mutenga, Staikouras (2008) \\
Globalization & Staikouras (2006) \\
& Artikis, Mutenga, Staikouras (2008) \\
Technological advances & Ryan (2001) \\
& Artikis, Mutenga, Staikouras (2008) \\
Increased customer sophistication & Ryan (2001) \\
Consumption and need to be satisfied & Falautano, Marsiglia (2003) \\
\hline
\end{tabular}

Source: Evija Dundure construction, based on scientific publications review

Based on the academic literature findings the authors stated the proposition to test for Latvia financial services market: Economic growth level and demography issues are negatively influencing development of Bancassurance in Latvia while regulation framework, globalization and technological advancement give positive impact.

\section{Motives for the Development of Bancassurance in Latvia}

In order to find out the motives for Bancassurance beginnings in Latvia it is worth to get a glimpse of history. It can be considered that the beginnings of Bancassurance in Latvia were marked with the formation of market economy - the establishment of private capital banks and insurance companies in the middle of 1990's. The first partnerships were created between banks and insurers fully or partly belonging to the same shareholders such as, for example, Parex bank and Parex Insurance company, Baltic Transit Bank and Latgarants. Both insurance companies exploited the possibility to expand throughout the territory of Latvia based on the cooperation with banks. The synergy of two financial services institutions was carried out in the interests of shareholders.

To start Bancassurance in all banks of Latvia definite pre-conditions had to be fulfilled - banks had to expand their retail lending activities and insurance policies had to become the part of required documentation to protect the banks in case of unexpected losses. The rapid expansion of mortgage credits started in year 2001 with total mortgage portfolio being 176 million EUR and reached its peak in 2008 with total amount of 12548 million EUR. Later, the years of crises brought the reduction and stabilization period reducing the mortgage portfolio to 4347 million EUR in year 2017 (www.fktk.lv).

During mortgage market growth period banks generated extra demand for mortgage insurance and initiated insured households' penetration ratio growth. Banks required certain standards of insurance terms and conditions and pushed insurers to the adjustments and risk coverage enlargement. Insurers observed additional revenue stream from the credit institutions and were tempting to accept the banks' wish-list.

Conforming to market tendencies in rapidly growing mortgage and car leasing market, insurance companies approached the banks to agree on the cooperation. From this moment Bancassurance started and its development continued in rather natural way - by expanding the banking products demanding the insurance policies to secure the banks from the losses. The insurance companies and banks came into distribution 
agreements to service the bank's clients by issuing relevant insurance policies and paying the commission fee to the bank.

According to experts' opinion Bancassurance in Latvia at its early stage was initiated by insurance companies who saw the potential of new clients and additional premiums. Later on, Bancassurance became the essential part of bankers' provided services. Competition in loans market developed and clients' service became one of the competitive advantages for banks. Clients preferred "one-stop shop" and banks were interested in clients' loyalty level increase. Bancassurance became the way how banks developed customer service and added value to the clients and increased their loyalty. Furthermore, another reason for entering into agreements with insurers became additional income for the banks. Banks chose the partners based on not only terms and conditions for the clients but also commission rate level paid to the bank. Commission income turned out to become permanent income source to cover part of bank's daily costs.

The experts' opinion based on the provided interviews was that initial reasons of Bancassurance in Latvia for banks were increase in customer service level and loyalty, for insurance companies - additional revenue stream and access to new clients.

For the banks requiring insurance policies from clients to cover their financial and mortgage risks Bancassurance can strengthen clients loyalty by providing "one-stop shop" services and create additional revenue stream.

\section{Market factors influence on Bancassurance in Latvia}

To test the proposition about academy stated market factors influence on Bancassurance in Latvia, the authors asked the interviewees to assess the definite external environmental factors: economic growth, demography, regulation restrictions, market growth, globalization and technological advances by giving the score from 1 to 5 where 1 means that there is no influence and 5 means high level of influence.

The highest scores were given to economic growth and technological advancement - 4,2 scores each. All other factors: market growth, globalization, regulatory environment and demographics scores ranged from 3,6 till 3,00 points accordingly (Figure 1).

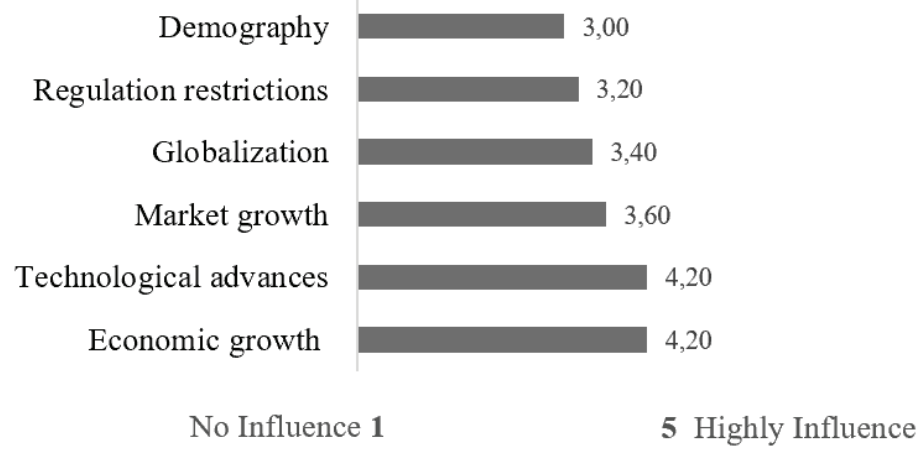

Figure 1: Market factors influence on Bancassurance development

Source: Evija Dundure, based on experts interviews and research results

Moreover, the experts ranged the factors not only in terms of level of influence but also gave the characteristics by answering the question - how the definite factor influence the Bancassurance: in a positive or negative way. The results in Figure 2 showed the positive impact of regulation environment, globalization and technological advances, negative factors were economic growth, market growth and demography. Let us give the overview of the market factors characterized by the experts. 


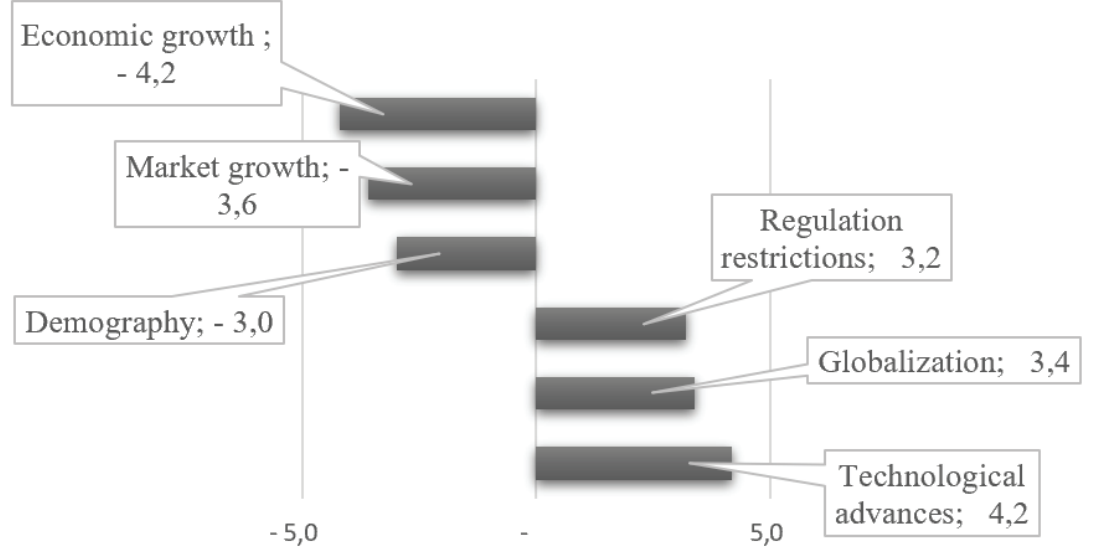

Figure 2: Nature of market factors influence on Bancassurance development in Latvia in year 2018 Source: Evija Dundure, based on experts interviews and research results

Economic growth. Majority of respondents rated economic growth and income levels as preconditions for development of Bancassurance in Latvia, also determining the overall success of business environment. Some experts pointed out that from insurer's perspective these factors are contributing to profitability of insurance industry, making non-life insurance businesses more attractive. Still the influence in recent years has not been very successful as the growth of the insurance market is mainly due to increase of premium level in motor insurance segment and not because of visible raise in number of policies. Other experts emphasized that these factors directly influence banks' ability to successfully deliver Bancassurance operations to primary client segments. This was particularly noticeable during the period of economic downturn as mortgage and leasing customers decreased significantly. Overall, almost all experts ranked this as one of the most fundamental market influencing factors of Bancassurance development in Latvia.

Technological development along with globalization allowed service providers to improve their offers by creating easy-to-use solutions for customers of financial service industry. This resonates with Bancassurance as delivery of services become technically possible through technological platforms, such as Google or Amazon. Swedbank, according to the experts is the most advanced company in terms of Bancassurance development and product delivery in Latvia, providing customers with ability to purchase insurance products using only few mouse clicks. Clearly the technology has led to higher level of Bancassurance integration into banking systems however the risk of losing clients to some Fintech platforms should also be taken into account.

Regulatory environment. One of the significant characteristics of regulatory environment in Latvia has been the ability for banks to co-operate with several insurers simultaneously. This allowed to choose Bancassurance model that favoured cooperation with several partners and complemented to a variety of insurance products offered to customers. Although most experts pointed out that a lot of the processes were dictated by the European Union (EU) making their implementation more complex than expected, it did not affect the performance of Bancassurance activities and services. Various experts highlighted the topicality of new EU General Data Protection Regulation (GDPR) and its impact on Bancassurance future. GDPR requirements can complicate the process since the customers should give consent to the data management and transfer to the third persons. At the same time GDPR caused upgrades of banks' IT systems to track personal data and implement a new mapping could give ground for better integration of Bancassurance therefore move to the next level of development. 
Globalization aspect utilization. Latvia is an open market for new financial services entrants and it was rated as relatively easy to implement market entry strategy from other EU insurance companies. The challenge in representing foreign country insurer could be in banks' ability to cover after sales services like claim handling and damage reimbursement. There were talks about the possibility to outsource these activities to a third party as it is successfully done in travel insurance where the same international claim adjusting agencies are used by nearly all companies. The reason why outsourcing of claims process is not primary choice in Latvian insurance market, is that insurance companies exercise claim handling process as a way to differentiate themselves from competitors, also giving the opportunity to establish stronger relationships with their clients for future cooperation.

Market growth. Scale and scalability are the aspects determining market potential to grow. Nevertheless, it is important to accentuate it specifically since almost all experts highlighted its importance for Latvia. In terms of providing Bancassurance services to private customers, the Latvian market is considered too small, thus in order to make a financially justifiable decision of establishing bank-owned insurance company the Baltic or even Scandinavian market would be more reasonable. The possibility to establish insurance company for the Baltic region with branches in all three countries allowed for example, Swedbank to reach the necessary scale level to become cost effective. Scale issue in on the bases of considerations for SEB Bank to create as much as possible similar Bancassurance model over the Baltic region. Mainly, Bancassurance from the banks' perspective is profitable when a large scale of private customer segment is targeted, and a simple product is delivered. Another reason mentioned by experts which cannot be overlooked is the necessity of specific insurance knowledge in insurance product distribution. Special knowledge is only accumulated when insurance services are experienced in a specific period of time, scale of operations, bank's portfolio and sales strategy largely contribute to this experience. Overall scale of bank's operations is seen by experts as a critical determinant in the Bancassurance integration process. It is profitable for a bank to transform to higher Bancassurance integration model only when a significant and thorough customer base is reached.

\section{Conclusions}

Bancassurance has become a significant component of financial service industry phenomenon all over the world. In Latvia banks and insurance companies enter into partnerships to take advantage of Bancassurance and make a profitable business in a small sized market.

By foundation of free capital market in Latvia at the beginning of 1990-ies, for newly established insurance companies and the banks Bancassurance has become the instrument of merging both institutions sales and administrative forces to reach the client and deliver larger scope of products. After entering the Europe Union on 2002 and Latvia legislation unification with EU regulations Bancassurance has become the regular way of cooperation form of banks and insurers. Banks became more internationally administrated as well as insurers were looking for partners out of their local countries. Therefore, Latvia financial market players entered global market with all its opportunities and limitations. From one size the globalization played its negative role for the banks on the financial crises 2008, from the other - it put the Bancassurance in the higher priority list as one of the non-banking financial services to cover the income gap.

Despite limited number of market players corresponding to the Bancassurance profile in Latvia dictated by low scale market size, the diversity in chosen cooperation models was recognised. Plus, the conducted interviews with all Bancassurance models' representatives provided a valuable insight into the dominating factors influencing the choice of cooperation mode as well as highlighted the problematic issues in the field.

The authors' assumption on a motive for beginnings of Bancassurance fully complied with reality - insurance companies expected additional revenue stream and access to new clients and banks followed the necessity to increase customer service level and loyalty.

Case study showed that market-based factors, such as economic and market growth, legislation, globalization, demography have high importance. However, special attention needs to be paid to the recent 
technological developments. On one side, in a slowly but steadily developing market environment new opportunities in information technologies give ground to enlarge companies' costs efficiency, whereas on the other - they are also influencing customer behaviour, changing their habits and intensifying competition environment. Banks and insurance companies have to consider the developments of Fintech company products to use them to their advantage.

The authors stated proposition: "Economic growth level and demography issues are negatively influencing development of Bancassurance in Latvia while regulation framework, globalization and technological advance give positive impact" fully complains with the research results.

For retail banks in Latvia, it is important to acknowledge the given economic and demographic situation, which negatively influences the growth of market and scale of local businesses. At the same time common legislative framework for all EU countries, open economy and high speed of technological improvements give the possibility to establish common Bancassurance processes not only for Baltic region but also Scandinavia, therefore making Bancassurance in the region more costs efficient. In this aspect international banks are in advantage to the ones working locally or not cooperating with sister companies in other countries they are represented in.

Although all banks in Latvia are operating in the same market conditions, the differences are in the applied strategy, and the character of operations create their unique position.

\section{References}

Alavudeen, R., Rosa, K. D. (2015). Growing Role of Bancassurance in Banking Sector. Bonfring International Journal of Industrial Engineering and Management Science, Vol. 5, p. 10-16.

Artikis, P., Mutenga, S., Staikouras, S. K. (2008). A practical approach to blend insurance in the banking network. The Journal of Risk Finance, Vol. 9, No. 2, p. 106-124.

Benoist, G. (2002) Bancassurance: The New Challenges. Geneva Papers on Risk and Insurance - Issues \& Practice, Vol. 27, No. 3, p. 295-303.

Bergendahl, G. (1995) The profitability of bancassurance for European banks. International Journal of Bank Marketing, Vol. 13, No. 1, p. 17-28.

Boonlertvanich, K. (2019) Service quality, satisfaction, trust, and loyalty: the moderating role of main-bank and wealth status. International Journal of Bank Marketing, Vol. 37, No. 1, p. 278-302.

Btrophy, R. (2013). Bancassurance: an insurance concept from a Irish perspective. Journal of Financial Regulation and Compliance, Vol. 21, No. 4, p. 319-333.

Chang, P. R., Peng, J. L., Fan, C. (2011). A Comparison of Bancassurance and Traditional Insurer Sales Channels. The Geneva Papers on Risk and Insurance Issues and Practice, Vol. 36, p. 76-93.

Chang, M., Elyasiani, E. (2015). Do Insurance Activities Enhance the Performance of Financial Services Holding Companies? Applied Economics, Vol. 47, No. 31-33, p. 3559-3576.

Chen, Z., Li, D., Liao, L., Moshirian, F., Szablocs, C. (2009). Expansion and consolidation of bancassurance in the 21st century. Journal of International Financial Markets, Institutions and Money, Vol. 19, No. 4, p. 633-644.

Diamond, D. (1984). Financial Intermediation and Delegated Monitoring. Review of Economic Studies, Vol. 51, p. 393-414.

Dominique-Ferreira, S. (2018). The key role played by intermediaries in the retail insurance distribution. International Journal of Retail \& Distribution Management, Vol. 46, No. 11-12, p. 1170-1192.

Elkington, W. (1993). Bancassurance. Chartered Building Societies Institutions Journal, Vol. 2-3.

Elyasiani, E., Wang, Y. (2012) Bank Holding Company Diversification and Production Efficiency. Applied Financial Economics, Vol. 22, No. 16-18, p. 1409-1428.

Falautano, I., Marsiglia, E. (2003). Integrated Distribution of Insurance and Financial Services and Value Creation: Challenges Ahead. Geneva Papers on Risk \& Insurance-Issues \& Practice, Vol. 28, No. 3, p. 481-494.

Fan, C. K., Cheng, C. (2011). An examination of key factors influencing bancassurance success - Taiwan and mainland China evidence. Service Industries Journal, Vol. 31, No. 11, p. 1887-1902.

Johnston, V. D. (1922). The Combination of Savings Deposits and Life Insurance. The University Journal of Business, Vol. 1, No. 1, p. 23-33.

Jongeneel, O. C. W. (2011). Bancassurance: Stale or Staunch? A pan-European country analysis, Vol. 53. 
Gonulal, S. O., Goulder, N., Lester, R. (2012). Bancassurance - a Valuable Tool for Developing Insurance in Emerging Markets. Policy Research Working Paper, No. 6196. World Bank, Washington, DC., p. 1-69.

Lymberopoulos, K., Chaniotakis, I. E., Soureli, M. (2004). Opportunities for banks to cross-sell insurance products in Greece. Journal of Financial Services Marketing, Vol. 9, No. 1, p. 34-48.

Mäenpää, I., Voutilainen, R. (2011). Value through combined offerings of bank and insurance, International Journal of Bank Marketing, Vol. 29, No. 7, p. 535-554.

Norman, L. (2007). Making bancassurance work: matching global power to local knowledge. International Journal of Bank Marketing, Vol. 25, No. 2, p. 117-119.

Okeahalam, C. C. (2008). Does Bancassurance Reduce the Price of Financial Service Products? Journal of Financial Services Research, Vol. 33, No. 3, p. 147-162.

Ryan, A. (2001). Financial regulation and the convergence scenario. Geneva Papers on Risk and Insurance, Vol. 26, p. 44-53.

Soureli, M., Lewis, B. R., Karantinou, K. M. (2008). Factors that affect consumers' cross-buying intention: a model for financial services. Journal of Financial Services Marketing, Vol. 13, p. 5-16.

Staikouras, S. K. (2006). Business Opportunities and Market Realities in Financial Conglomerates. The Geneva Papers on Risk and Insurance Issues and Practice, Vol. 31, p. 124-148.

Swiss, R. (1992). Bancassurance: A Survey of competition between banking and insurance. Sigma, Vol. 2, p. 4. Switzerland.

\title{
RINKOS APLINKOS VEIKSNIU ITAKA BANKU IR DRAUDIMO BENDROVIŲ PARTNERYSTÉS PLÉTRAI L A T V I J O J E
}

\author{
Evija Dundure, Biruta Sloka
}

(Latvijos universitetas, Latvija)

\section{Santrauka}

Bankai ir draudikai, dalyvaujantys finansinių paslaugų sektoriuje, bendradarbiauja, remdamiesi (angl.) bancassurance koncepcija (tai partnerystès susitarimas tarpininkaujant tarp banko ir draudimo bendrovès). Šiuo klausimu atliekami keli tyrimai, daugiausia dèmesio skiriant masto ekonomikai ir daugelio bancassurance bendrų modelių veikimui. Šiuo tyrimu siekta nustatyti pagrindinius rinkos aplinkos veiksnius, kurie daro įtaką mažmeninių bankų Latvijoje draudimo plètrai ir augimo lygiui.

Ekonominiai rodikliai, įskaitant ekonomikos augimą, iliustruoja rinkos raidą, jos gebėjimą gaminti ir pirkti, būtinybę finansuoti ir apdrausti. Viena pagrindinių 1990 m. ir 2000 m. pasaulinio vystymosi skatinimo varomuju jègų - reguliavimo ir teisèkūros aplinkos skirtumai, kurie pastaraisiais metais bancassurance srityje vis labiau aktualūs. Užsienio šalyse matoma daugiau tokių bankų ir draudimo bendrovių partnerystès pavyzdžių, o tai įdomu ir aktualu mokslininkams.

Tai leido bankams ir draudimo bendrovėms patekti ị naujas rinkas ir sukurti veiklą naujuose regionuose. Globalizacijos sąlygomis manoma, kad užsienio rinkų liberalizavimas užsienio bendrovèms ne tik leis taps partneriu fiziškai neatidarius padalinio kitoje šalyje, bet ir pradès greitai bei netrukdomai atlikti visas operacijas. Technologijų plètra lemia pardavimų tinklo kūrimo ir paslaugų teikimo sąnaudų efektyvumą. Tai lemia klientų elgesị ir naujus pirkimo ịpročius.

Atliekant tyrimą siekta: išanalizuoti, kaip rinkos aplinkos veiksniai veikia bankų draudimo plètrą Latvijoje. Tikslai: 1) išanalizuoti mokslines publikacijas ir ankstesnių tyrimų rezultatus; 2) ištirti bankų draudimo plètrą skatinančius veiksnius; 3) palyginti finansų rinkų ekspertų ir bankų atstovų nuomonių skirtumus dèl veiksnių, kurie turi įtakos bankų draudimui Latvijoje. Šis straipsnis orientuotas ị Latvijos rinką, kur taikomi keli bancassurance modeliai: pateikiami pasiūlymai, apklausus pagrindinių suinteresuotųjų šalių atstovus ir išanalizavus antrinius rinkos duomenis. Tyrimo rezultatai: Latvijos bankų ir draudimo bendrovių motyvai 
igyvendinant bancassurance iš esmès teigiami: nauji klientai ir papildomos pajamos draudikams, klientų aptarnavimo gerinimas ir lojalumas bankams. Tyrimo rezultatai atskleide didelị ekonomikos augimo ir technologijų plètros poveikị bancassurance kitiems rinkos veiksniams ir jų integracijos svarbą, siekiant geresnių rezultatų kiekvieno taikomo bancassurance modelio atveju. Be to, technologine pažanga, globalizacijos ir reguliavimo ribojimas yra veiksniai, teigiamai veikiantys bankų ir draudimo bendrovių partnerystę, tuo tarpu kai Latvijos demografinè padètis veikia neigiamai.

PAGRINDINIAI ŽODŽIAI: banku draudimas, bankai, draudimas, rinkos aplinka.

JEL KLASIFIKACIJA: M10; M38

Received: 2019-03-14

Revised: 2019-04-24

Accepted: 2019-05-15 